\title{
HUMANITY/PLAN; OR, ON THE "STATELESS" TODAY (ALSO BEING AN ANTHROPOLOGY OF GLOBAL HEALTH)
}

\section{TOBIAS REES \\ McGill University}

\section{October 2010}

I am in Atlanta, Georgia, at the annual HIV Vaccine conference. The event is organized by the Global HIV Vaccine Enterprise (the Enterprise), a spin-off of the Bill and Melinda Gates Foundation (BMGF) that was launched in 2005 to better integrate HIV vaccine research on a global scale. The conference welcome gift - aside from the usual brochures, programs, and pens - is "The 2010 Scientific Strategic Plan of the Global HIV Vaccine Enterprise” (Bernstein et al. 2010)

I have been following the formulation of this plan since 2009. For almost two years I have been sitting through meetings in hotel rooms in Paris, in New York, in Bethesda, listening to administrators, scientists, funders, industry representatives, and activists from all continents discussing how to best achieve the Enterprise's ambitious task - to transform the rather dispersed, dramatically underfunded, and, on the level of nomenclature and technology, largely incommensurable HIV vaccine labs into a single, closely integrated research community. The plan they eventually came up with suggested organizing HIV vaccine research in form of a carefully designed, global division of labor, held together by a single experimental system continuously monitored and adapted by the Enterprise.

I had traveled to Atlanta in hopes of engaging a few scientists in a conversation about the future the Scientific Strategic Plan (SSP) had envisioned for them. But there is no need to engage the conference participants, for the roughly one 
thousand scientists from almost fifty countries attending HIV Vaccine 2010 are engaged. There is much talk about the plan's bold vision, its futility, its genius. Journalists flock to the room reserved for the Enterprise, and representatives from the BMGF, the AIDS Vaccine Advocacy Coalition (AVAC), the World Health Organization (WHO), the Canadian government, the U.S. military, and UNAIDS comment on the SSP in special sessions and meetings. Amid all this talk about "the plan," I become fascinated by what I had simply taken for granted thus far-planning.

What actually is planning? Since when is there such a practice? And what is a plan?

\section{PLAN/PLANNING}

Halfway through the conference I start searching the Internet for articles on the plan and on planning. ${ }^{1}$ From etymological websites I learn three things. First, planning is a rather novel form of practice. In European languages the term did not exist before the seventeenth century. Second, planning is a distinctively modern form. To plan is to come up with a rationally thought-through scheme of action for how to achieve a particular objective. Its realization, which often involves technical measures, is overseen with administrative or bureaucratic accuracy. And third, the plan and planning document the fantastic, dreamy side of modernity. This has many reasons. One is that planning is not doing. The planner-often conflated with the project maker — is one whose business is to come up with plans, not to realize them. Another one is that the figure of the planner often appears endowed with too much fantasy. Planners have the aura of the fantast. A planner may ceaselessly invent plans for futures that are too fantastic, less than needed, sometimes less than desirable. Plans may abound, actualizations don't.

I conclude that planning oscillates between the feasible and the fantastic.

As I follow the conversations about the SSP, I can easily identify the modern technical aspect of the plan (the feasible) — it develops a map of the field, of how different centers (some yet to be built) should collaborate, of what the appropriate next steps might be. ${ }^{2}$ But what, I wonder, is its fantastic side? What is the bold future that it dreams of? Shortly after I scribble this question in my notebook, I hear Alan Bernstein, ${ }^{3}$ the executive director of the Enterprise, the master planner, say, "This plan is a plan for humanity."

I look around me. People nod. I am baffled: a plan for humanity? 


\section{HUMANITY (BIOLOGICAL)}

Bernstein's statement gripped me. Humanity? Was this the bold future? The fantastic side of the SSP?

I withdrew to my hotel room and read through my field notes. One of the most striking findings of my research have been stories that I grouped together under the category negative humanity experience.

These stories almost always came in the same form: A scientist or doctor narrated how deeply she or he was moved by travels to Africa in the mid- to late 1990s (that is, after ARVs, antiretroviral drugs, first became available in Western countries). What they found moving was not so much poverty, misery, or the absence of a medical infrastructure, but rather their encounters with Others who were dying familiar deaths, deaths they knew from their work with AIDS patients in the United States or in Europe. Having seen death caused by the virus at home, and having seen death caused by the virus elsewhere, led those who shared their stories with me to a recognition between the familiar and the foreign, a recognition of what they called, in unison, "humanity."

I had found these stories striking for two reasons.

First, there was the form the humanity experience took. It was not, as one might perhaps assume, a variant of existentialism and its rather familiar ethical ramifications - human beings are those beings who know about their own mortality; who suffer from this knowledge; and who have the additional ethical potential to recognize the Other as equally knowing/suffering, a recognition that (where it occurs) has the powerful consequence of humans becoming solidary neighbors in death. The key argument of this twentieth-century philosophy had been that humans differed from animals - from the merely biological — by their existential knowledge and their ethical potential. In sharp contrast, the humanity experiences I was told about were grounded in the powerful experience of a shared biology. Here humans were coming into view not as more than biologybut as biology. As living organisms, biologically constituted, inseparably related through a single phylogenetic tree, exposed to similar pathogens. I am almost inclined to speak of a powerful experience/discovery of a biological continuuma continuum (a biological humanism) made visible by the deadly work of a virus.

Second, while many described the humanity experience as beautiful - there was widespread use of an aesthetic vocabulary — all of them experienced it as well as deeply troubling: for the people in Africa were "still" dying deaths that North Americans and Europeans were basically no longer dying. 
The effect of ARVs, as José Esparza from the BMGF provocatively put it, was that AIDS became another "tropical disease."

The conclusion that most of my interlocutors drew from this tropicalization of AIDS was that humanity did and did not yet exist. Or, as Steven Wakefield from the HIV Trials Network taught me: humanity is present through its absence. It is rather a future, something we work toward. It is not a reality, yet.

I found these humanity experiences remarkable. I was moved by the negative form - presence through absence - my interlocutors gave to it. And I was struck by the fact that humanity was articulated in biological, even in evolutionary terms (a curious inversion of the nineteenth- and twentieth-century racisms that set humans apart). But I also was never quite sure what to do with these stories. As moving as they were - they seemed to me rather marginal to my actual curiosity.

How does one actually put in place, maintain, and advance - on a world scale - a single experimental system? How to standardize assays, cell media, nomenclature, and the like? How does one convince researchers with diverse backgrounds (and stakes), working in different countries, on different continents, to participate in a massive, global division of labor?

I thought of myself as studying the work-infrastructurally as well as conceptually — that would make the emergence of a global biology possible (Franklin et al. 2000; Cambrosio and Keating 2012; Collier and Ong 2005; Rabinow 1989). And at times I imagined the Enterprise preparing a global biomodern projecta project that brings cutting-edge biology to remote places and people to modernize their biology (or at least their biological circumstances of existence). ${ }^{5}$ The humanity stories I had collected were not unrelated to this research imaginaryand yet, they had no real place in it either. Or did they?

"This is a plan for humanity."

The effect of Bernstein's statement (though perhaps made in passing, without any second thoughts), coupled with my new appreciation of planning as a most curious practice (one oscillating between the feasible and the fantastic), was that my understanding of the stakes of my research was profoundly set in motion.

What were the links between humanity and planning? Between the biological humanity experiences and the effort of grounding all HIV vaccine research in a single experimental system?

Thinking through these questions, my fieldwork endeavor gradually began to appear to me in a new light. If humanity (understood as a moral, biological challenge) does not yet exist, if it is a future anticipated in the present, then couldn't one say that a most plausible (or modern) way of responding to this 
challenge is to come up with a plan for how to achieve this future? With a plan, as Bernstein put it, for humanity?

Walking through the Omni Hotel in Atlanta, I no longer saw scientists and activists and administrators. Instead I saw myself surrounded by a diverse set of practitioners of humanity - funders of humanity, technicians of humanity, bureaucrats and administrators of humanity, and planners of humanity. ${ }^{6}$ They understand humans in biological terms and experience the (moral) challenge of humanity as at stake in biological research - as at stake at the bench, at stake in getting oneself immersed in the nitty-gritty details of experimental work, in building a global infrastructure, in the standardization of nomenclature and technologies. As the problem is rather complex, and resources rather minimal, humanity requires planning. Hence the creation of a planning bureau for humanitythe Global HIV Vaccine Enterprise.

I got tremendously excited about my discovery. On the one hand, it radically changed what was at stake in my research. To be sure, I am still interested in the administrative and technical effort of the Enterprise to establish a single global experimental system. But now this single experimental system appeared to me as the material basis of a global, biological humanity plan. To formulate the SSP, to establish standardized bio-assays, to convene conversations about innate or mucosal immunity, to conduct clinical trials - this is work toward humanity. My ethnographic study of the Enterprise is literally an ethnography of humanity in the making. On the other hand, it generated a most fascinating set of new research questions. If humanity is less of a given - a collective singular of which all humans are part - than a future anticipated in the present, a project in need of planners, then one may ask how the Enterprise's humanity plan differs from previous conceptions of humanity. How does it continue — or depart from — what I now would call earlier humanity plans (and projects)? Is there a difference in style, ethos, problem, approach? What difference(s)?

\section{THE POSSIBILITY OF AN ANTHROPOLOGY OF HUMANITY}

I left Atlanta with an idée fixe. Conceptual historians have frequently shown that an all-encompassing, truly global concept of humanity is a product, in Europe, of the late eighteenth century. Roughly sketched, it first appeared in French and soon thereafter in German and English (Foucault 1966; Ritter 2004; Koselleck 1979). What if I took my discovery literally? What if one approached all the documents written during the past 250 years as if they were plans? As if they were planning sketches for how to achieve what does not yet exist, humanity? 
Hasn't humanity been, from the moment of its emergence in the late eighteenth century, a future potential? A potential equally in need of poets and planners?

Implicit in these fieldwork-generated questions was a whole research program: read the great (literary and administrative) works about humanity not as local conceptual breakthroughs to the universal but as expressions of the fantastic side of (European) modernity (here defined as the age of planning; see Gadamer 1966).

It also seemed to me that these questions opened up a huge analytical space where before there was nothing but taken-for-grantedness. They transformed a given (all humans constitute the totality of humanity) into a provincial, historical, contingent phenomenon, thereby engendering the possibility of an anthropology of humanity; one that grounds in an ethnographic exploration of a set of actorsthe practitioners of humanity - that, despite its extraordinary significance, is usually nowhere accounted for, one that calls for a meticulous epistemology of humanity plans (Chakrabarty 2000). The promise, the beauty, of such an anthropology of humanity is that it would bring into sharp analytical view mutations in the way humanity is thought of (conceptually) and sought to be achieved (practically). ${ }^{7}$

Does the Enterprise, does the SSP, stand in for such a mutation?

At the same time I felt derailed - derailed by the powerful (nominalist) implication of my discovery: that humanity is not a given, but an invention (a plan); that it is not a timeless, independent object out there, but the rather recent product of inventors (planners); that it does not exist independently of the plans and planners that imagine it.

No plan, no humanity.

\section{(THIS IS NOT) A HISTORY OF HUMANITY PLANS}

After I returned to Montreal I started to work my way through available histories of humanity. What I found was that the majority of authors concerned with humanity took it for granted that humanity comes in form of a family of nations. For the majority, humans were not as such, not as individuals, members of humanity_but as members of a given nation (Arendt [1951] 1958; Gehlen 1973; Kohn 1944; Lévi-Strauss 1952; Niezen 2008). ${ }^{8}$

What I found as well, and this came as a major surprise, was that most of the authors who first wrote about humanity actually understood their texts as humanity plans (Krajewski 2006). The eighteenth-century authors of humanity and the nation, this is to say, were aware of the relative newness of these terms- 
a newness that opened up novel spaces of thought and politics (the term nation acquires its modern meaning only in the late eighteenth century; see Hobsbawm 1990).

What is more, they were clearly aware that to achieve the future humanity/ the nation opened up, amounted to a revolutionary challenge (Foucault 2003). If humanity, or so the key argument of their plans went, is composed of nations, then isn't the only way to achieve humanity to make nations - rather than kingsthe principle of all politics? Wasn't the way forward to establish nation-states, that is, states constituted by a national society, states that would have only one reason to exist, namely, to foster their own society? ${ }^{9}$

The first humanity plans thus were revolutionary calls to action-and the way to achieve humanity was to establish a plurality of nation-states, one for every European nation, each of which would then evolve around the principle of fostering the national society (on the link between nation, humanity, and the European revolutions, see Anderson 1991; Hobsbawm 1990; Gellner 1983; Malkki 1992; on the rise of society fostering and early conceptions of social welfare, see Desrosières 2002; Foucault 1978). ${ }^{10}$

In the late eighteenth century, humanity was a rather European, and national, affair. This began to gradually change only during the long nineteenth century (Hobsbawm 1962, 1975, 1987): once European nation-states had emerged, two new kinds of humanity plan were formulated.

The first one was internationalism. European countries and the United States began to work out an administrative and legal framework for the international affairs that no single nation-state could address alone (Faries 1915; Geyer and Paulmann 2001; Huber 2006; Iriye 1997). ${ }^{11}$

The second one - it emerged slightly later-was empire building. Backed up by a linear philosophy of history and convinced of their own modernity, European countries like France, Belgium, England, and Germany claimed that they alone had broken through to universality (to science, economy, administration, technology) and were therefore alone in the position of allowing for humanity (Kramer 1979; Fabian 1982; Said 1978). It was their self-proclaimed civilizational duty to build empires and thereby lift other nations into the future (Aldrich 1996; Conklin 1998; Crowder 1964; Mamdani 1996).

One could call the first two lines internal, for they concerned themselves with the relatively small number of sovereign nation-states in the European (and American) tradition, while one could call the third one external, for it dealt with non-Europeans. 
In the "short twentieth century" (Hobsbawm 1994), the external line gradually faded. As empires began to crumble, as decolonialization movements began to rise (first in Asia then in Africa), the way to plan humanity was increasingly seen in the global imposition of the nation-state form as it had emerged in late eighteenth-century Europe, and in the establishment of international agreements and institutions (Staples 2006). The concrete form this idea took after World War II was, on the one hand, the creation of the United Nations system, and, on the other hand, the massive funding and support of new nations - usually in form of developmental aid, which one could interpret as an indirect continuation of empire building (Luard 1982; Ziring et al. 1994; for a critique, see Balibar 1991; Malkki 1992).

The British philosopher Jonathan Ree (1992, 9-10) elegantly captured the logic that has, at least retrospectively, organized humanity planning: "To generate a plurality of sovereign nation states," each one endowed with the task of fostering its national society, "in order that, for any human being, there should be a definite answer to the question 'which nation is responsible?"”

Now what if one juxtaposes the SSP of the Enterprise with the nationcentered humanity plans of the past two and a half centuries, especially with the global imposition of the nation-state form that dominated the second half of the twentieth century? The contrast is most striking conceptually (how humanity is thought of) as well as practically (how humanity is sought to be achieved).

Conceptually: Nowhere in the SSP are nations or a family of nations evoked. The assumption that one is a member of humanity by way of belonging to a nation is radically absent. Instead, humanity is evoked in biological terms, as a global continuum composed of individual biological beings that are the product of a shared evolutionary history; it is borderless, nationless, and yet not without local specificity (HIV comes in many local variants). ${ }^{12}$

Practically: The actual building (achieving) of humanity under the nationstate plan has been the task of national governments and intergovernmental organizations. For example, the way to achieve world health has been to encourage (as the WHO actively did) each government to offer health services as part of its national society building and fostering practice (call it — with Foucault 1978biopower). The SSP calls on neither nation-states nor international organizations. Instead, the practice of humanity building - in accordance with the biological understanding of humanity — is the task of biological and medical research facilities, clinical trial sites, pharmaceutical companies, activist networks, philanthropies, consulting companies, community advisory boards, transnational organiza- 
tions, and various NGOs (for closely related arguments, see Nguyen 2010; Petryna 2009; Redfield 2013). An assemblage of sites, institutions, and actors not reducible to the idea of nations as the basic building blocks of humanity, an assemblage that potentially undermines it, sets it in motion, points elsewhere (Nguyen 2005).

How to make sense of this rupture?

\section{HOW THE VITAL WAS DECOUPLED FROM THE SOCIAL (ON THE RISE OF GLOBAL HEALTH)}

The emergence of what I called a "global biological humanity project" is inseparably related to the entry of the World Bank, traditionally focused on socioeconomic development, into world health (Brown et al. 2006; Godlee 1994; Walt 1993; Zwi 2000). In the 1980s, the World Bank issued its first exclusively health-related loan, and it has since steadily increased its health-related spending (becoming, from a financial point of view, the most significant investor in world health; see Institute of Health Metrics and Evaluation 2013). The rationale informing the bank's entry into a terrain formerly considered beyond its mandate was the belief — spelled out in the 1987 World Bank Report (the first exclusively concerned with health) — that health is a financial issue and must be treated as such. Evoking the financial crisis of the 1970s, the World Bank proposed to relieve nation-states of their health-care obligation toward their citizens and encouraged privatization - a move opposed to the national society-building projects advertised by the UN and, in particular, by the WHO (World Bank 1980, 1987; Ruger 2005; Stein 2008).

The consequences of the shift from a public, social welfare to a privatized, market-based conception of health care were, on the level of world health, disastrous - especially in countries that had no or almost no health-care infrastructure to privatize (for a helpful review, see Pfeiffer and Chapman 2010).

The reforms introduced, or demanded, by the World Bank had the effect that large portions of humanity were left with no or almost no access to health care and that the nations formerly responsible for establishing it were relieved (if this is the right term) of their duty to do so-precisely at the time when HIV was spreading dramatically.

In the mid- to late 1990s (when ARVs became available) it became apparent that there were large parts of humanity for which - from the perspective of humanity planning — no nation held responsibility any more. Health had quite literally transformed into a fallow field in which humanity, an unprotected, vul- 
nerable humanity, was at stake. It was a biological humanity threatened by disease that the established institutions formerly in charge of health (the nation-state, the WHO) could not (or would not) take care of (Brown et al. 2006; Breman and Shelton 2007). Humanity, if it was to be achieved, required new institutions, efforts, plans, and practices - a requirement gradually identified by health activists (think of the humanity stories referred to above) and addressed by the emergence of what became known as the global health movement, made up of a series of organizations that have come into existence since the late 1990s: in 1998 the Global Health Council; in 2000 the Bill and Melinda Gates Foundation and the GAVI Alliance; in 2001 the Global Fund to Fight AIDS, Malaria, and Tuberculosis; in 2002 the Millennium Project and DATA; in 2003 Millennium Promise and PEPFAR; in 2005 the CHAI initiative, the Consortium of Universities for Global Health, and the Global HIV Vaccine Enterprise; in 2006 Product Red and Malaria No More; in 2007 the Institute of Health Metrics and Evaluation.

During the past decade, the work of these global health organizations has gained a (powerful) dynamic of its own. They have generated a vision of a global, biological humanity that has - conceptually as well as practically-outgrown the older nation-state plan of humanity. In addition, they have effectively marginalized the two institutions formerly alone responsible for world health: the nation-state and the WHO.

Could one claim, therefore, that the specificity of the Enterprise's biological humanity plan is precisely that it has historicized the nation-state form of humanity? That organizations like the Enterprise have succeeded it? ${ }^{13}$ More radically put, could one claim that such organizations have mutated what humanity is and thus who holds responsibility for it?

How could one conceptually capture the difference the SSP makes?

\section{STATELESS}

The anthropological literature operates with several powerful concepts to analytically make sense of organizations like the Enterprise. They are shown to foster biological citizens (Petryna 2002); bring about biosocialities (Rabinow 1996); establish a logic of experimentality (Petryna 2009; Nguyen 2010); ground minimal biopolitics (Redfield 2006a); undermine sovereignty and create states of exception (notably Fassin 2011); or foster a "will to live" (Biehl 2007).

Most of these concepts share a negative assessment of the definition of humans in biological terms; they suggest, sometimes implicitly, sometimes explicitly, that the exclusively biological approach produces an animalization insofar 
as it ignores the social and political dignity constitutive of humans, a dignity best ensured by national-society-fostering states (Agamben 1998; Badiou 2007).

While I find many of the concepts used helpful - experimentality is established, biosocialties are fostered - my fieldwork has made me wonder about the appropriateness of the normativity they often transport. To be more precise, my research has made me wonder if the articulated norm does not simply reflect the nation-state plan of humanity - a plan that relies on the conceptual presupposition that humans are national beings, that is, constitutive of a national polity/society and that proper humanity building must take the form of fostering the political foundation of states, so that humans, as basic elements of the polity, can flourish. ${ }^{14}$

From the perspective of the anthropology of humanity I have sought to articulate here, humanity is not a given. Instead it is a plan - or something to be planned. What it is - or whether it is something at all - depends on how (if at all) it is planned (and on how the plan is put in practice). It follows that the idea of a family of nations - or the assumption that humans are first and foremost national, societal, political beings - is simply one plan among various possible ones. $^{15}$

The task of an anthropological exploration of humanity plans can, therefore, hardly be to normatively judge a novel plan in terms of an already established one. Rather, the challenge would be to ask what difference a novel plan makes, to bring it into view in its own right, with its own dynamics, on its own terms, to make accessible and palpable the novel space it opens up for humanity to exist.

Today, what is humanity becoming?

In the final part of this essay, I endeavor to offer such a conceptual effortin the form of a rearticulation of the concept of the stateless as it is has been introduced by Hannah Arendt.

In her Origins of Totalitarianism, Arendt ([1951] 1958) tells the story of the stateless in form of a drama with its origins in the French Revolution. The dilemma of 1789 , she suggested, was that, while the revolutionaries sought to ground the law in Man himself, they did not institutionalize the Rights of Man (the law) in a juridico-political state apparatus (also see Arendt 1961, 1972, 2005). Instead, they assumed that the "inalienable Rights of Man would find their guarantee and become an inalienable part of the right of the people to sovereign self-government" (Arendt [1951] 1958, 291). ${ }^{16}$ This assumption, according to Arendt, implied the factual abolition of the state (understood here, following Hegel, as a legal apparatus set apart from the nation). In other words, the law was now no longer a matter of the state- but of the nation (les peuples Français) for the nation (the 
French). The disastrous potential of this abolition of the state became visible only after World War I, with the falling apart - in part caused by intense national upheavals - of the empires of Russia and Austria-Hungary.

The story is well known. The western European nation-states, guided by the League of Nations, established all over eastern and southeastern Europe sovereign nation-states as defined by the 1789 and 1848 revolutions, according to which each nation - defined in terms of a purity of population - had a right to its own territory and its sovereign self-government. The problem was, however, that in an area where many nations shared one territory, the idea of national sovereignty could hardly be realized. Identity of nation and territory was possible only when the nations not involved in government were denaturalized and classified as minority nations, that is, as alien nations within nations, as nations without their proper territory, without their own government, and hence without any legal apparatus to guarantee their political rights. And this is precisely what happened:

"The emergence of minorities in Eastern and Southern Europe" made visible the problem of the nation-state form that arose with the French Revolution: "The moment human beings lacked their own government no authority was left to protect them and no institution was willing to guarantee them" (Arendt ([1951] 1958, 292, 269).

To grasp the full critical intent of Arendt's account of the stateless - the brutal realism it articulates - one has to recall that built into her account is a normative Aristotelian argument, according to which humans are biological beings with the additional capacity to organize themselves politically. The concept of humans Arendt upholds is a juridico-political one. Only as member of a polity can one be a political being, can one be more than a mere animal. It follows that the concept of the stateless not merely points to a group of people beyond the reach of the law. Instead it points to a group of humans that is, precisely insofar as they are beyond the law, deprived of what sets them apart from mere animals: their juridico-political dignity.

What makes Arendt relevant here is her presupposition - not questioned at all by her critique of the nation-state form - that the possibility of human dignity is contingent on politics, and that the possibility of politics is contingent on the state.

Couldn't one claim that it is precisely this presupposition - this impossibility, in 1951, to think humanity independent of the state - that gives contour to the difference the humanity plan of the Global HIV Vaccine Enterprise makes? 
Couldn't one claim that the space opened up for humanity by the SSP of the Enterprise is a space beyond this presupposition? A space beyond the state- but also beyond the juxtaposition of the merely biological and the political upheld by Arendt (and by most anthropologies of global health)?

The conceptual suggestion I would like to make here is that the specificity of the Enterprise's SSP - the specificity of the new space it opens up for humanity - is best understood as a (provocative) positive rearticulation of the stateless.

I will make three comparative points to illustrate this suggestion.

1. I begin with the apparent. The conception of the human that guides the nationstate plan of humanity is - or so Arendt is usually understood - a sociopolitical one. ${ }^{17}$ The humanity practice of the nation-state ideally was or has been the responsibility to assure and maintain the social conditions of existence (health has been one of them). In this sense, one could state that the nation-state form is less a humanity-achieving than a humanity-securing practice. In sharp contrast, the sociopolitical remains absent from the Enterprise's humanity plan. The humanity at stake in the SSP is a biological rather than a sociopolitical conception of the human. In fact, it is rooted so firmly in a straightforward biological conceptionin talk about viruses, immunity, molecules, genes, proteins, genomes, and evolution - that almost all of my interlocutors find the distinction at the core of the nation-state form, here mere biology, there free political existence, implausible.

“Aren't human beings more than merely biological," I asked Yegor Voronin, a staff member of the Enterprise?

"More?," he asked me with a baffled face.

"Yes, more." I explained. "We are also social or political beings, no?"

His response: "Maybe man is social, maybe political, I am not sure about that. But if there are such traits in humans, then it is because of their biology."

He paused and then added: "The epigenetic is still genetic."

That is, from a strictly biological perspective, humans are (what else?) biological beings. And if they are political _ even if politics is understood as an open, non-determined space (Arendt 2007) — then only insofar as their biology allows for politics and the open.

2. From the perspective of the nation-state humanity plan, the stateless is a negative category, a temporal condition that needs resolution. For to be stateless is to have lost one's human dignity, is to be nothing but human, part of a 
naked humanity. In the perspective of the Enterprise, the stateless appears in a different, (almost) positive light. The Enterprise de facto focuses on and seeks to achieve humanity in the form of the stateless, whether at home or abroad.

To a certain degree one may even say that the Enterprise - or the BMGFopposes the nation-state plan of humanity (it understands itself as an alternative or as a historical successor), for it looks at the nation-state as a failed humanity project, precisely because the humanity that the nation-state secures is always an exclusive one, one focused on the nation - on the national society - only. The non-national other - and hence the majority - is always left out.

In contrast, the Enterprise defines humans biologically, defines them in inclusive, global terms. To be sure, the members of the Enterprise have nothing against social organization. But this is a project only states can offer-and states are exclusive. Hence, the social — insofar as it depends on the nation-state formis not the level of organization on which humanity can be achieved. More emphatically, one cannot think a global humanity in national or societal terms. Therefore, the Enterprise departs from the national society-fostering logic and focuses on a different, entirely inclusive level - the biological one (see also Nguyen 2005). ${ }^{18}$

3. What follows from the first two comparative observations is that the talk about a "minimum humanity" or a "minimal definition" of the human as a living species often evoked when it comes to humanitarian aid does not make sense if addressed to the Enterprise (Barnett 2011; Fassin 2011; Fox 1995; Redfield 2006b). The Enterprise, just like classical medical humanitarianism, is interested in stateless humans. The difference between the Enterprise and classical humanitarianism, however, is that the latter works under the so-called emergency paradigm. It offers a minimal biopolitics - secures the bare life of the temporarily stateless in a time of crisis - until the state can take over again (Redfield 2006a).

In the humanity plan of the Enterprise, this orientation toward the state is entirely absent. ${ }^{19}$ This has led some to the claim-directly or indirectly - that institutions like the Enterprise lock others into an animal existence, that they reduce others to mere biological beings. Or that they create a permanent state of exception in which the sovereign self-government of the people is suspended. Both these claims, however, only make sense if one subscribes to the nation-state plan of humanity: only if humans are defined as more than biological-and only if the task of the nation-state is to secure this "more" (at least for its national society)_does such a critique make sense. 
I conclude my conceptual effort by suggesting that from the perspective of the Enterprise (and this probably holds true for other global health organizations), the stateless constitutes a positive space precisely insofar as it allows for a humanity beyond the corrupt, exclusive, and failed nation-state form. For those who shared their work and motivation with me, the stateless is a promise - the promise of a global (biological) humanity. The very least one can say, independent of how one relates to this positivization of the stateless, is that it amounts to a major mutation of the 250-year-old space that has opened up the possibility of humanity. ${ }^{20}$ And to a massive analytical, conceptual and critical, challenge for the human sciences. ${ }^{21}$

\title{
ANTHROPOLOGY OF KNOWLEDGE/THINKING
}

As an anthropologist of knowledge/thinking, I am interested in events that mutate the space of possibility within which we can think about the human, about humanity. To be more precise, I am interested in events that open up the possibility of thinking and acting in ways that escape previously established concepts and categories. Such events pose a challenge to critical analysis - precisely insofar as they cannot be grasped in terms of the already known, they may require new, not yet existing analytical tools and thoughts. They require an analysis of motion, in terms of motion.

The power (and aim) of the Enterprise is to undermine the already knownthis includes our aesthetic as much as our moral and political vocabularies - and the power of an anthropology of knowledge/thinking lies in that it can ethnographically investigate the open spaces that such an undermining produces. It can critically, beyond the norms of the already established, assess these new spaces in which humanity is today thought of and sought to be realized. How to enter these spaces, leaving behind anachronistic forms and concepts but not critical potential, is a major but most fascinating challenge.

"Il faut une science politique nouvelle," Tocqueville $(1835,9)$ once wrote, “à un monde tout nouveau. Mais c' est à quoi nous ne songeons guère."22

\begin{abstract}
My fieldwork among HIV vaccine researchers, activists, and funders has led me to suggest that humanity - when it was first conceived of in the late eighteenth century-emerged as a plan, a plan for how to establish a future anticipated in the present. The powerful implication of this fieldwork-based suggestion is that what humanity is - or if it is at all — depends on the available humanity plans. I argue in this essay that we are currently seeing the emergence of a new-a biological-
\end{abstract}


humanity plan, and I wish to make visible that — and how- this biological humanity plan has outgrown, conceptually as well as institutionally, older humanity plans. I also hope to make comprehensible the massive - intellectual as well as politicalchallenge this emergence poses. [global health; Gates Foundation; humanity; humanitarianism]

\section{NOTES}

Acknowledgments I am grateful to Alan Bernstein and the members of the Global HIV Vaccine Enterprise for many conversations. Without their generosity my research would have been impossible. Miriam Ticktin carefully read the paper and helped me improve it immensely. Without our conversations about global health and humanity I could not have written this essay. Peter Redfield has consistently encouraged me, and I have greatly gained from our conversations about the social, the vital, and about provocation. Nell Gabiam has read and commented on earlier drafts of the present article and has helped me to avoid conceptual pitfalls. I would also like to thank Fiona Gedeon Achi, Lawrence Cohen, Nicole Rigillo, Sharon Kaufman, and Vincanne Adams for their support and encouragement - and the faculty and graduate students of the Department of Anthropology at the University of Washington, where a much earlier version of this piece was presented. Finally, I would like to acknowledge the helpful guidance of Charlie Piot and Anne Allison.

1. I am aware that an Internet search in a hotel room hardly counts as research. Yet my fieldwork has led me to make a distinction between fieldwork - understood as a powerful method to generate unexpected, surprising research questions - and research, by which I mean the actual working through these surprising questions. And it seems to me as if at least some of these field-generated questions are such that they are better worked through by turning away from the actual field and to archives or already published material. Here fieldwork, there research. Consequently, the fieldwork episodes (discovery stories) I provide here are neither meant as "thick description" (Geertz 1973) nor as "thick analysis" (Cohen 2000). Rather, they trace the unexpected emergence of a powerful new research question.

2. First, if indirect, steps toward an anthropology of planning have been taken by Rabinow 1989, 2003, Luhmann 2007, and Collier 2011. See also the still powerful analysis of Gadamer 1966.

3. Alan Bernstein left the Enterprise in summer 2011. He was replaced by William Snow. Along with the change in leadership went a new orientation to what the Enterprise is and aims to achieve.

4. It was not always clear to me what was meant by humanity. The recognition that a concrete Other shared something fundamental with oneself? Or the recognition of a global collective called humanity, which is constituted by something all share? Or both?

5. I am grateful to Stephen Collier for our exchanges about biomodernism. The background to these have been discussions of Rabinow 1989 and 1996.

6. Ilana Feldman $(2011,417)$ speaks insightfully about "humanity practices."

7. My thinking about an anthropology of humanity has gained tremendously from conversations with Miriam Ticktin and Samual Moyn. Ticktin and Feldman (2010) have offered a powerful, if in orientation slightly different, version of such an anthropology of humanity - an anthropologically scrupulous study of humanity claims, that is, of claims that one is working in the name of humanity. What is the humanity at stake in such claims? Who is entitled to speak of humanity? What are the power relations? More specifically, they are interested in what, in terms of power and politics, these claims enable and what they leave in the dark. See as well Ticktin 2011 and Feldman 2011. And see the seminal Malkki 1994. Moyn, in addition to his extraordinary The Last Utopia (2010), has launched the journal Humanity, devoted exclusively to the analysis of the many-faceted discourses on and practices of humanity. That Europe cannot possibly be 
the limit of an anthropology of humanity has been powerfully documented by Faisal Devji (2008) and Samera Eismar (2006, 2011).

8. In this section I work through a large amount of literature, without having space to do justice to its complexity. Yet I think that the basic argument holds up to critical scrutiny: that when humanity was first articulated as a concept, it came in the form of a family of nations. It is striking to note that many of the histories of the nation-state can be read as histories of humanity. In fact, Anderson 1991, Foucault 1966, Gellner 1983, Hobsbawm 1990, Niezen 2008, Malkki 2002, and Ree 1992 all present their works, at least in part, as accounts of humanity.

9. Not only do both concepts - humanity and nation - emerge in eighteenth-century revolutionary discourses but they also emerge as mutually constitutive of one another: humanity was said to require nations, and nations were said to be constitutive of humanity. As Liisa Malkki $(1992,54)$ observed more than twenty years ago: "That the world should be composed of sovereign, spatially discontinuous units is a sometimes implicit, sometimes stated premise in much of the literature on nations and nationalism."

10. One may well argue that some thinkers of the nation-state had little or no interest in humanity. Yet these exceptions do not undermine that humanity was first conceptualized as a family of nations, each one of which would ideally have its proper territory and state.

11. A first if perhaps not powerful and largely Western institutionalization was the League of Nations (Henig 2010).

12. I am inclined to push the argument even further. During the planning meetings convened by the Enterprise I heard the assumption expressed that nation-states were in no position to address the challenge, because they tended to look at their own humans and national societies, rather than at humanity in general. What is needed now, and this is precisely the ethos that inspires the Enterprise (and, as far as I can tell, much of the BMGF), are novel forms of action, undertaken by non-state actors, grounded in science. "For science," as Bernstein explained, "knows no borders."

13. Independent of how one answers these questions, one can at the very least say that during the past decade and half, a new humanity plan has emerged, one that does not define humanity in national societal but in global biological terms. Global is here understood as a space constituted by non-state actors independent of any nation..

14. Biological care would then form part of the national society-building service offered by the state. That is, humans are first national beings - and then, as national beings, biological organisms to be cared for (Foucault 1978).

15. What, then, of politics? What if the Enterprise - the space it opens up for humanityescapes the established political (and critical) vocabulary? Would the challenge not be to research what new, what other forms of politics - beyond the nation, beyond society-are emerging today?

16. "In other words, man had hardly appeared as a completely emancipated completely isolated being who carried his dignity within himself without reference to some larger encompassing order, when he disappeared again into a member of a people." As a consequence, "Only the emancipated sovereignty of the people, of one's own people, seemed to be able to insure them. As mankind, since the French Revolution, was conceived in the image of a family of nations, it gradually became self-evident that the people, and not the individual, was the image of man" (Arendt [1951] 1958, 291).

17. I write "is usually understood," for this is not Arendt's actual argument. For her, the social is equivalent with the biological, and this is precisely what defies proper politicswhich should unfold beyond the merely biological.

18. My intervention "What about race?," was countered with the comment that race is not a biological but a social concept, with a reference to Lewontin 1972.

19. States may be part of the story, but the story is not a state one but a stateless one.

20. Note that I am not suggesting that it is the first mutation ever, for it surely is not. The whole point of the approach is to suggest that every change in a plan —or in the way 
it is set to practice - equates a mutation. But some mutations are minor, while otherslike the one I seek to assess in this essay-are major.

21. A stateless humanity? How does the Enterprise, or the BMGF, actually imagine such a stateless humanity? My research led me to think that this is perhaps the wrong question, for it mistakes the fantastic for the feasible. The anticipated stateless humanity - a future exemplarily enacted on a small scale in a few select places - is perhaps better understood as a powerful critique of the nation-state than as a fully worked-out alternative to it. Perhaps this is the dreamy, the fantastic, side of the SSP?

22. In my free rendering: A radically new world requires, if it is to be understood, a new political vocabulary, but this we do not even dare to dream of.

\section{REFERENCES}

Agamben, Giorgio

1998 Homo Sacer: Sovereign Power and Bare Life. Stanford, Calif.: Stanford University Press.

Aldrich, Richard

1996 Education for the Nation. London: Cassell.

Anderson, Benedict

1991 Imagined Communities: Reflections on the Origin and Spread of Nationalism. Revised

Arendt, Hannah and extended edition. London: Verso.

(1951) 1958 Origins of Totalitarianism. New York: Meridian.

1961 Between Past and Future: Six Exercises in Political Thought. New York: Viking.

1972 Crisis of the Republic: Lying in Politics; Civil Disobedience; On Violence; Thoughts on Politics and Revolution. New York: Harcourt, Brace, Jovnovich.

2007 The Promise of Politics. New York: Schocken.

Badiou, Alain

2007 The Century. London: Polity.

Balibar, Etienne

1991 "The Nation-Form: History and Ideology." In Race, Nation, Class: Ambiguous Identities, edited by Etienne Balibar and Immanuel Wallerstein, 86-106. New York: Verso.

Barnett, Michael

2011 Empire of Humanity: A History of Humanitarianism. Ithaca, N.Y.: Cornell University Press.

Bernstein et al.

2010 “The 2010 Scientific Strategic Plan of the Global HIV Vaccine Enterprise.” Nature Medicine 16, no. 9: 981-89. http://dx.doi.org/10.1038/nm0910-981.

Biehl, João

2007 Will to Live: AIDS Therapies and the Politics of Survival. Princeton, N.J.: Princeton University Press.

Breman, Anna, and Carolyn Shelton

2007 “Structural Adjustment Programs and Health." In Globalization and Health, edited by Ichiro Kawachi and Sarah Wamala, 219-33. Oxford: Oxford University Press.

Brown, Theodore, Marcos Cueto, and Elizabeth Fee

2006 "The World Health Organization and the Transition From 'International' to 'Global' Public Health.” American Journal of Public Health 96, no. 1: 62-72. http://dx.doi.org/10.2105/AJPH.2004.050831.

Cambrosio, Albert, and Peter Keating

2012 Cancer on Trial: Oncology as a New Style of Practice. Chicago: University of Chicago Press.

Chakrabarty, Dipesh

2000 Provincializing Europe: Postcolonial Thought and Historical Difference. Princeton, N.J.: Princeton University Press. 
Cohen, Lawrence

2000 No Aging In India: Alzheimer's, the Bad Family, and Other Modern Things. Berkeley: University of California Press.

Collier, Stephen

2011 Post-Soviet Social: Neoliberalism, Social Modernity, Biopolitics. Princeton, N.J.: Princeton University Press.

Collier, Stephen, and Aihwa Ong, eds.

2005 Global Assemblages: Technology, Politics, and Ethics as Anthropological Problems. Oxford: Blackwell.

Conklin, Alice

1998 A Mission to Civilize: The Republican Idea of Empire in France and West Africa 18951930. Stanford, Calif.: Stanford University Press.

Crowder, Michael

1964 "Indirect Rule__French and British Style." Africa: Journal of the International African Institute 34, no. 3: 197-205. http://dx.doi.org/10.2307/1158021.

Desrosières, Alain

2002 The Politics of Large Numbers: A History of Statistical Reasoning. Cambridge, Mass.: Harvard University Press.

Devji, Faisal

2008 The Terrorist in Search of Humanity. New York: Columbia University Press.

Eismar, Samera

2006 “On Making Dehumanization Possible.” PMLA 121, no. 5: 1544-51. http:// dx.doi.org/10.1632/pmla.2006.121.5.1515.

2011 "At Once Human and Not Human: Law, Gender and Historical Becoming in Colonial Egypt." Journal of Gender and History 23, no. 2: 235-49. http:// dx.doi.org/10.1111/j.1468-0424.2011.01636.x.

Fabian, Johannes

1982 Time and the Other: How Anthropology Makes its Object. New York: Columbia University Press.

Faries, John

1915 The Rise of Internationalism. PhD dissertation. Columbia University.

Fassin, Didier

2011 Humanitarian Reason: A Moral History of the Present. Berkeley: University of California Press.

Feldman, Ilana

2011 "Ad Hoc Humanity: UN Peacekeeping and the Limits of International Community in Gaza.” American Anthropologist 112, no. 3: 416-29. http:// dx.doi.org/10.1111/j.1548-1433.2010.01249.x.

Feldman, Ilana, and Miriam Ticktin, eds.

2010 In the Name of Humanity: The Government of Threat and Care. Durham, N.C.: Duke University Press.

Foucault, Michel

1966 Les Mots et les Choses. Paris: Gallimard.

1978 The History of Sexuality, Vol. 1. New York: Vintage.

2003 "Society Must Be Defended": Lectures at the Collège de France, 1975-1976. Edited by F. E. Michel Senellart, Alessandro Fontana, and Arnold Davidson. New York: Picador.

Fox, Renée C.

1995 "Medical Humanitarianism and Human Rights: Reflections on Doctors Without Borders and Doctors of the World." Social Science and Medicine 41, no. 12: 160726. http://dx.doi.org/10.1016/0277-9536(95)00144-V.

Franklin, Sarah, Celia Lury, and Jackie Stacey

2000 Global Nature, Global Culture. Thousand Oaks, Calif.: Sage.

Gadamer, Hans-Georg

1966 “Notes on Planning for the Future." Daedalus 95, no. 2: 572-89. 
Geertz, Clifford

1973 The Interpretation of Culture. New York: Basic Books.

Gehlen, Arnold

1973 Moral und Hypermoral. Eine pluralistische Ethik. Frankfurt a. M.: Athenäum.

Gellner, Ernest

1983 Nations and Nationalism. Ithaca, N.Y.: Cornell University Press.

Geyer, Martin, and Johannes Paulmann

2001 The Mechanics of Internationalism: Culture, Society, and Politics from the 1840s to the First World War. Oxford: Oxford University Press.

Godlee, Fiona

1994 "The World Health Organisation: WHO in Crisis." BMJ 309:1424-28. http://

Henig, Ruth dx.doi.org/10.1136/bmj.309.6966.1424.

2010 The League of Nations: The Makers of the Modern World. London: Haus Publishing.

Hobsbawm, Eric

1962 The Age of Revolution. Europe 1789-1848. New York: Vintage.

1975 The Age of Capital. Europe 1848-1875. London: Weidenfeld and Nicolsen.

1987 The Age of Empire. Europe 1875-1914. London: Weidenfeld and Nicolsen.

1990 Nations and Nationalism Since 1780: Programme, Myths, Reality. Cambridge:

Cambridge University Press.

1994 The Age of Extremes. The Short Twentieth Century, 1914-1991. New York: Vintage.

Huber, Valeska

2006 "The Unification of the Globe by Disease? The International Sanitary Conferences on Cholera, 1851-1894.” Historical Journal 49, no. 2: 453-76. http:// dx.doi.org/10.1017/S0018246X06005280.

Institute of Health Metrics and Evaluation

2013 Financing Health 2012: The End of the Golden Age? Seattle: Institute of Health Metrics and Evaluation.

Iriye, Akira

1997 Cultural Internationalism and World Order. Baltimore, Md.: Johns Hopkins University Press.

Kohn, Hans

1944 Nationalism: Its Meaning and History. New York: McMillan.

Koselleck, Reinhardt

1979 Vergangene Zukunft: Zur Semantik Geschichtlicher Zeiten. Frankfurt am Main: Suhrkamp.

Krajewski, Markus

2006 Restlosigkeit: Weltprojekte um 1900. Frankfurt a. M.: Fischer Verlag.

Kramer, Fritz

1979 Verkehrte Welten: Zur Imaginären Ethnographie des 19. Jahrhunderts. Frankfurt a. M.: Syndikat.

Lévi-Strauss, Claude

1952 Race et Histoire. Paris: UNESCO.

Lewontin, Richard

1972 "The Apportionment of Human Diversity." Evolutionary Biology 6:391-98.

Luard, Evan http://dx.doi.org/10.1007/978-1-4684-9063-3_14.

1982 A History of the United Nations: The Age of Decolonization, 1955-1965. New York: Macmillan.

Luhmann, Niklas

2007 Politische Planung: Aufsätze zur Soziologie von Politik und Verwaltung. Opladen:

Malkki, Liisa Westdeutscher Verlag.

1992 "National Geographic: The Rooting of Peoples and the Territorialization of 
National Identity among Scholars and Refugees." Cultural Anthropology 7, no. 2: 24 44. http://dx.doi.org/10.1525/can.1992.7.1.02a00030.

1994 "Citizens of Humanity: Internationalism and the Imagined Community of Nations." Diaspora: A Journal of Transnational Studies 3, no. 1: 41-68. http:// dx.doi.org/10.1353/dsp.1994.0013.

Mamdani, Mahmood

1996 Citizen and Subject: Contemporary Africa and the Legacy of Late Colonialism. Princeton, N.J.: Princeton University Press.

Moyn, Samuel

2010 The Last Utopia: Human Rights in History. Cambridge, Mass.: Harvard University Press.

Nguyen, Vinh-Kim

2005 “Antiretroviral Globalism, Biopolitics, and Therapeutic Citizenship." In Global Assemblages: Technology, Politics, and Ethics as Anthropological Problems, edited by Stephen Collier and Aihwa Ong, 124 44. Oxford: Blackwell.

2010 The Republic of Therapy: Triage and Sovereignty in West Africa's Time of AIDS. Durham, N.C.: Duke University Press.

Niezen, Ronald

2008 “The Aufklärung's Human Discipline: Comparative Anthropology According to Kant, Herder and Wilhelm von Humboldt." Intellectual History Review 19, no. 2: 177-95. http://dx.doi.org/10.1080/17496970902722890.

Petryna, Adriana

2002 Life Exposed: Biological Citizenship After Chernobyl. Princeton, N.J.: Princeton University Press.

2009 When Experiments Travel: Clinical Trials and the Global Search for Human Subjects. Princeton, N.J.: Princeton University Press.

Pfeiffer, James, and Rachel Chapman

2010 "Anthropological Perspectives on Structural Adjustment and Public Health." Annual Reviews in Anthropology 39:149-65. http://dx.doi.org/10.1146/ annurev.anthro.012809.105101.

Rabinow, Paul

1989 French Modern: Norms and Forms of the Social Environment. Cambridge, Mass.: MIT Press.

1996 Essays on the Anthropology of Reason. Princeton, N.J.: Princeton University Press.

2003 Anthropos Today: Reflections on Modern Equipment. Princeton, N.J.: Princeton University Press.

Redfield, Peter

2006a "Doctors, Borders and Life in Crisis." Cultural Anthropology 20, no. 3: 328-61. http://dx.doi.org/10.1525/can.2005.20.3.328.

2006b “A Less Modest Witness.” American Ethnologist 33, no 1: 3-26. http:// dx.doi.org/10.1525/ae.2006.33.1.3.

2013 Life in Crisis: The Ethical Journey of Doctors Without Borders. Berkeley: University of California Press.

Ree, Jonathan

1992 "Internationality." Radical Philosophy, no. 60: 3-11.

Rees, Tobias

2010 "Being Neurologically Human Today: Life, Science, and Adult Cerebral Plasticity (An Ethical Analysis).” American Ethnologist 37, no. 1: 150-66. http://

Ritter, Henning dx.doi.org/10.1111/j.1548-1425.2010.01247.x.

2004 Nahes und Fernes Unglück: Versuch über das Mitleid. München: C.H. Beck.

Ruger, Jennifer Prah

2005 "The Changing Role of the World Bank in Global Health in Historical Perspective." American Journal of Public Health 95, no.1: 60-70. http:// dx.doi.org/10.2105\%2FAJPH. 2004.042002. 
Said, Edward

1978 Orientalism. New York: Pantheon.

Staples, Amy

2006 Birth of Development: How the World Bank, Food and Agriculture Organization, and World Health Organization Changed the World, 1945-1965. Kent, Ohio: Kent State University Press.

Stein, Howard

2008 Beyond the World Bank Agenda: An Institutional Approach to Development. Chicago: University of Chicago Press.

Ticktin, Miriam

2011 Casualties of Care: Immigration and the Politics of Humanitarianism in France. Berkeley: University of California Press.

Tocqueville, Alexis de

1835 De la Démocratie en Amérique. Paris: Flammarion.

Walt, Gill

1993 "WHO Under Stress: Implications for Health Policy." Health Policy 24:125-44.

World Bank http://dx.doi.org/10.1016/0168-8510(93)90030-S.

1980 World Development Report 1980. Washington, DC: World Bank.

1987 Financing Health Services in Developing Countries: An Agenda for Reform. Washington, DC: World Bank.

Ziring, Lawrence, Robert Riggs, and Jack C. Plano

1994 The United Nations: International Organization and World Politics. Belmont, Calif.: Thomas Wadsworth.

Zwi, Anthony

2000 "Policy Forum: The World Bank and International Health." Social Science \& Medicine 50, no. 2: 167-68. 